Bond University

Research Repository

\title{
Pervasive incentives, disparate innovation and intellectual property law
}

\author{
Van Caenegem, William
}

Published in:

Intellectual Property Policy Reform

DOI:

$10.4337 / 9781848449039.00020$

Licence:

CC BY-NC-ND

Link to output in Bond University research repository.

Recommended citation(APA):

Van Caenegem, W. (2009). Pervasive incentives, disparate innovation and intellectual property law. In C. Arup, \& W. van Caenegem (Eds.), Intellectual Property Policy Reform: Fostering Innovation and Development (pp. 250-266). Edward Elgar Publishing. https://doi.org/10.4337/9781848449039.00020

\section{General rights}

Copyright and moral rights for the publications made accessible in the public portal are retained by the authors and/or other copyright owners and it is a condition of accessing publications that users recognise and abide by the legal requirements associated with these rights.

For more information, or if you believe that this document breaches copyright, please contact the Bond University research repository coordinator. 


\section{Bond University}

\section{ePublications@bond}

Law Faculty Publications

Faculty of Law

$1-1-2009$

\section{Pervasive incentives, disparate innovation and intellectual property}

William Van Caenegem

Bond University, william_van_caenegem@bond.edu.au

Follow this and additional works at: http://epublications.bond.edu.au/law_pubs

Part of the Intellectual Property Law Commons

\section{Recommended Citation}

Van Caenegem, William, "Pervasive incentives, disparate innovation and intellectual property" (2009). Law Faculty Publications. Paper 315 .

http://epublications.bond.edu.au/law_pubs/315

This Book Chapter is brought to you by the Faculty of Law at ePublications@bond. It has been accepted for inclusion in Law Faculty Publications by an authorized administrator of ePublications@bond. For more information, please contact Bond University's Repository Coordinator. 


\section{Chapter}

Pervasive incentives, disparate innovation and intellectual property law

William Van Caenegem

\section{Introduction}

Current interest in patent policy reaches beyond the academic community, as two recent newspaper articles demonstrate: one concerned how 'a new technique for creating embryo-free human stem cells sidesteps a controversial US patent that has slowed the pace of scientific discovery worldwide .... ${ }^{, 1}$ James Thomson of the University of Wisconsin generated the patent but also the breakthrough which circumvents it. Since another group simultaneously reported the technique no 'one team can control it', according to the author. The other article related to the Australian National University (ANU), which was told by the Australian Universities Quality Audit (AUQA) to 'better promote the intellectual property attached to its research to raise its profile'. ${ }^{2}$ AUQA stressed that even if the ANU was not set to make much money from exploiting IP, at least exploitation 'could raise ANU's standing in the global community’. ${ }^{3}$

The first story illustrates that diverse and unpredictable events affect the value of patents. Patenting has created a dense web of rights within which interactions and exchanges occur in a highly complex and contingent manner. Single invention, single 
patent, single product linear innovation is not the norm. The second story has a now familiar ring to it: patents can play a significant (but unintentional) role in enhancing the value of goodwill or reputation attached to an innovator's brand. Below the surface, however, lies a meta-tale about patent policy’s constant adaptation and mutation in response to theoretical critiques or uncomfortable empirical data: that patents do not actually induce innovation does not matter so much, since they have the benefit of strengthening your reputation.

The 'mutation' literature and the rising tide of condemnatory critiques of the patents system, ${ }^{4}$ invite us to revisit the complex relationship between intellectual property law and creativity within a contemporary industrial and commercial context. Creativity flourishes not simply because of incentives provided by intellectual property rights (IPRs), or specifically by patents in the industrial context; rather, all IPR's interact dynamically with multiple other factors to influence the nature, locality, direction and volume of creative output - whether in the arts or industry. The other factors that engender creativity, or, focussing on industry, that act as incentives to invent are so multifarious and complex in their interaction that they are difficult to map. ${ }^{5}$ Nonetheless, we should not shrink from contextual accounts of the role of IPRs; in that light I revisit the account of patents as incentives within a contemporary socioeconomic context below.

Attention is first drawn to the perceived core role of patents as an incentive for firms to invent. Then the focus shifts to incentives for individuals to invent, or more particularly to generate, divulge and realise inventive ideas. In relation to the former I suggest that it is arguable that in the light of the pervasiveness of incentives to invent 
in contemporary industry and society the need for patents as incentives must be exposed to serious debate. At best patents could amount to little more than an additional and superfluous incentive. It may be that the account of patents as incentives to invent is so uncertain, that a perception of patents as measures to enhance competition in particular circumstances should be preferred.

In relation to individuals I argue that because incentives pervade society, innovation is disparate, that is, it happens simultaneously and heterogeneously in multiple organisations. This generates the need for legal instruments that underpin coordination of innovation, and also for legal settings that enhance the transfer of knowledge and information between organisations. Perhaps the most significant mechanism by which the latter occurs is through the mobility of knowledgeable individuals between organisations. In terms of the law, this means that employees should not be subject to unwarranted restraints, whether contractual or equitable, on their ability to draw on all they have learned from previous employment (in the same way that they can draw freely on anything learned during formal courses of instruction). Furthermore, in making their choices as to where their know-how and creative abilities will be most productively used they must be as free as possible from legal restraints on their use of knowledge. This freedom will have beneficial effects in terms of innovation performance.

\section{Pervasive incentives for innovation in firms and the need for patents}

\section{A. Patents as incentives to invent}


Patents are said to constitute a critical incentive to invent. However, clearly a patent per se cannot operate as an incentive - a patent imposes costs. In fact the incentive is the potential return from monopolistic exploitation. But this return is very uncertain at the time of patenting, and many patents are never turned to account, so that the cost is never offset by monopoly gains. If one is turned to account, it is not clear to what extent profits are increased by the patent - in other words, would equivalent returns on an innovation have been generated in the absence of the patent? Further it is not clear at what level the incentive is supposed to operate - at the individual or the firm level? At the very least, considerable uncertainty surrounds the incentive account. Below I make an attempt to address it by rephrasing the incentive question: rather than ask 'Does a patent work as an incentive to invent?', I ask 'Is there a shortage of incentives to invent which requires an additional incentive in the form of a technology monopoly?'. This is not a question to which I attempt to give a definitive answer; rather I point out that it is arguable both at the socio-cultural level, and at the industrial or economic level, that incentives to invent already pervade society in the absence of patents. This affects the account that posits that firms require an additional regulatory incentive to invent.

Although there is no underlying consensus about the inducement effects of patents or about the need for patents as an incentive across industry, they are certainly perceived by both participants and commentators to be crucial in particular sectors, pharma being the outstanding example. But we have to be cautious in interpreting that fact as supporting the incentive theory of patents. The pharmaceutical products sector has certain very particular characteristics: the marketed product and the patented 
invention tend to be coextensive ${ }^{6}$ the risk and sunk cost of investment in adopted research pathways is high, with great potential for total losses; ${ }^{7}$ alternative strategies to appropriate the advantages from innovation are largely inoperable; the potential lifespan of the product is relatively long; the cost of imitation and reverse-engineering is low; the required skills in manufacturing are generic and readily available; there is little room for product improvements and enhancements; and potential imitators tend to be highly informed and highly skilled. Substitution by new technologies (new drugs) is potentially the most significant source of competition in the sector, yet it is stymied by these characteristics, which may be further aggravated by particular conditions in any given geographical market. Products in other sectors may be different in any number of crucial respects: the patent and the product not coextensive; the time to market shorter; risks and expense of R\&D smaller; potential for continual improvements greater; natural barriers to imitation higher (imitation lag is greater); secrecy more useable; other (legal) appropriation strategies available and the like. Think software for instance, where the need for patents is greatly contested.

So, rather than demonstrating a lack of incentive to invent new drugs, the perceived sectoral importance of patents points to the peculiar characteristics of that product sector: they militate against dynamic competition by introduction of new technologies. There is good ground for arguing there is a competition problem, which could be efficiently addressed by a technology monopoly, but it is not at all clear that there is an incentive problem. To expand this beyond the pharmaceuticals sector, the problem a technology monopoly might usefully address is a failure of competition in particular product sectors, rather than a lack of incentives to invent in industry. 


\section{B. Pervasive incentives to invent}

In reality incentives to invent pervade post-industrial society. The healthcare sector is a paradigmatic example of this: nowhere is the incentive to generate new solutions stronger. This pervasiveness is apparent both at the individual and socio-cultural level, and at the level of industry and the economy. Furthermore, the significance of the former cannot be ignored at the level of the latter: social and cultural factors that compel people to invent also impact at the level of the economy. They cannot be ignored in favour of an exclusively 'financial' analysis at the firm level.

In industrialised nations such as those in North America, Europe and Australasia, a high premium is attached to individual creativity and originality. Conversely, copying, imitation and 'following' are ascribed less value. ${ }^{8}$ The culture of individualism engendering personal originality and creativity is very strong. In other words, in a technological setting, there is a strong cultural incentive to search for new and creative practical answers to problems, rather than to meet them with fatalistic acceptance or an exclusively spiritual response. This applies to even the most intractable issues facing society, whether they be more social (for example, sexism in society) or environmental (for instance, global warming or disease).

There is also a strong socio-cultural innovation pull resulting from public perceptions about science: it is perceived as a potential source of new solutions to most problems. In other words, people inherently expect that solutions to problems will emerge from new and creative applications of scientific knowledge; science is not exclusively valued for its own sake. The public automatically assumes that creative individuals 
are somewhere engaged in plumbing the depths of science to find new solutions to problems.

At the more institutional level of education and research, creativity, inventiveness and originality are also core values. Solid peer-review based incentive mechanisms underpin and institutionalise the search for new and original ideas and insights. Prize and other evaluation systems focus on creativity, novelty and originality, as does assessment for publication. The whole tendency of science and humanities research and teaching is towards the new, original and different. Scientific research is dynamic, with an exponential growth in new knowledge in decentralised and multifarious institutions. None of this new knowledge would come about without deep and pervasive personal and institutional incentives. These incentives also compel individuals to seek out and immerse themselves in new environments that will enhance their own creative output and inventiveness. Labour market policy tends to prioritise mobility, so that the expectation that knowledgeable individuals will seek out the most fertile environment for creative work can be fulfilled.

Another factor encouraging innovation is both socio-cultural and market based: consumer focus on novelty. ${ }^{9}$ The latest is the best, and much advertising, product development and market strategising is centred on and accelerates the cultural desire for the new and different. There is a constant demand for new versions and enhancements, improvements, changes in design and so on. At the same time society is very techno-focussed: technology pervades lives and technology always changes and, either in reality or in perception improves our lives over time. This view may not 
be universally accepted, but it is sufficiently pervasive to be a significant force in society.

Economically or industrially also incentives for firms to innovate are pervasive. The conditions that now sustain the drive to innovate in industry are completely different from what prevailed during the industrial age. Then information channels were few, they operated slowly and were not universally accessible. Education levels were poor. The industrial infrastructure was heavy, solid and difficult to replace, lead times for innovation in plant and machinery were long, and specialisation in machine manufacture was not as advanced as it is now. The risks inherent in innovation in industry, with potential downtime and so forth were very high. Anti-competitive conduct was not actively policed. Innovation was not a central competitive strategy because neither supply nor demand factors were as solid and pervasive as they are now. Investment levels in basic and applied research in the public and private sectors, in education were far lower than they are today. Innovation was not disparate and widely distributed, nor so comprehensively studied or serviced in terms of management, the law and finance.

In contrast, in this day and age innovation is a central competitive strategy for firms. Innovation-thinking permeates industry in most sectors of economic activity. No business can afford not to innovate or at least adopt innovation as a significant competitive strategy, whether at the level of business practices or technology. This competitive imperative is absolutely critical to thinking about patents law - if innovating is overwhelmingly mandated by competitive market conditions then the justification for patents becomes less obvious. At the same time a solid educational 
and broader infrastructure further encourages and enables innovation in industry: apart from general education in science and technology, specialists study innovation and teach it in business and management schools around the industrialised world. ${ }^{10}$ Modern technology is readily available, including R\&D focussed instruments and machinery - in other words there is a dynamic specialist tooling sector that underpins innovation in industry.

At the same time, flexible and innovative financial and management tools are constantly being refined to generate the required capital and management expertise to bring innovations to market. Various kinds of risk financing are possible and available, with sectorial specialisation. Underpinning that activity are the legal skills and tools required to bring innovation to fruition in a complex and multifarious market with diverse and dispersed actors. ${ }^{11}$ This infrastructure invites the pursuit of constant improvements, adaptations and developments, while the university and research sectors provide a matching supply of new information, knowledge and data that can be turned to account. The focus on ensuring diffusion by commercialisation of public sector innovations is now very strong.

Today, innovation is not sporadic or occasional but continuous - not innovating automatically equals losing the competitive race. Innovating is not a choice but an inevitable necessity, an essential survival mechanism.

The above account seeks to give prominence to the centrality of the innovation dynamic in post-industrial society both at the socio-cultural and economic level. This suggests that strong incentives to invent may already operate pervasively. Ascribing 
some merit to this account detracts from the potency of the incentive theory in patents law, that is, that patent monopolies, which come at a well documented cost, ${ }^{12}$ are required because incentives to invent are lacking. That may have been the case in the past, but it is at the very least more contestable in a modern society and economy with genuinely competitive markets.

\section{Problems with competition rather than incentives?}

If we assume no shortage of incentives to innovate in a post-industrial economic climate, what does this mean for patents? Part of the answer may lie in the early origins of the system: patents offered protection for the introduction and establishment of industries relying on technologies new to the realm (either by invention or from abroad). In a market whose competitiveness had been corroded by the irresponsible grant of monopolies in existing trades and industries, patents encouraged competition by new entry into local manufacturing ${ }^{13}$. A lack of competition was addressed by the grant of narrow monopolies (technology based, rather than product or industry based), encouraging new entrants to compete with incumbents. The grant in itself guaranteed no return to the grantee.

Another pointer is the generally accepted fact, canvassed above, that certain product sectors such as pharma consider patents to be crucial. Yet as also contended above, at the same time medicine is an area of science and research where the incentive to innovate is strongest: the social impetus is compelling and public $R \& D$ investment correspondingly high; peer-based incentive structures operate acutely; and demand for new health solutions is close to insatiable. So arguably it is not a lack of incentives 
that necessitates patents here; it must be something else. The most obvious source is the presence in the pharma sector of the kind of conditions, discussed above ${ }^{14}$, which strongly deter new technological entrants, and for which a state granted technological monopoly may be an effective remedy. In contrast, competition failures in other product sectors may neither be amenable to ‘the gale of creative destruction' nor responsive to the grant of a technological monopoly. Other competition enhancing regulatory measures (competition policy provisions) may be more appropriate. Yet as we know, patents apply without distinction to all technological products and processes, without express regard to the competition context - therein perhaps lies the rub.

\section{Patents as competition law}

All this points towards fashioning patents law into an instrument for addressing competition failures in industries with certain product and market characteristics, rather than regarding it as a mechanism to redress a shortfall in incentives to

innovate. ${ }^{15}$ The preconditions of grant and scope of the exclusive right should be adapted to modify stagnant markets by the introduction of temporary technological monopolies. If viewed in this manner the whole patents system is integrated into the broader complex of competition law. The apparent contradiction between patent monopolies and competition policy/regulation dissolves and the two can operate seamlessly to address competition deficiencies across all markets by different remedial interventions (some of which will be technological monopolies but others not). ${ }^{16}$ 
On a less ambitious scale, at the very least a competition focus suggests a conservative approach to patent extension. In the absence of the clearest evidence of competition failure in some identifiable product/process market, which a technological monopoly is actually adapted to redress, the boundaries of patentability should not be extended. ${ }^{18}$ Debates should go beyond the question of whether some new area involves technology, and centre on whether competition failure exists and is of a kind which can be efficiently addressed by grants of technological monopolies. Critiques of the patent system are now commonplace, and the approach above simply reinforces conclusions suggested by different angles of approach, which are largely based on concerns about proliferation and poor administration.

\section{E. Pervasive innovation, private ordering and mobility}

Because incentives to innovate pervade society their effect is dispersed: they operate on many and diverse actors, resulting in polycentric and disparate innovation. Multiple independent firms and organisations in private and public sectors initiate innovation. As a result information and knowledge is generated and held in disparate locations by different actors. ${ }^{18}$ Innovation is not centrally planned nor solely Government controlled. Information and knowledge is everywhere and not limited to specific reservoirs and channels.

An acute need for efficient coordination and diffusion results from this polycentricity. Innovation while disparate remains highly interdependent. Dispersed actors need to learn and acquire previously or concurrently accumulated knowledge and data from each other. Knowledge and information has multiple possible uses which may be 
recognised and exploited by others rather than by the actual holder or creator. There must be a system of revealing and exchanging dispersed knowledge and information. Our system is complex and organically grown: it incorporates the public domain, embedded in a number of structures, and the proprietary domain in which communication and diffusion on the basis of the rules of intellectual property plays a significant role. ${ }^{19}$

But non-proprietary legal mechanisms also impact significantly on how knowledge is revealed, dispersed and exchanged between diverse actors. Equity and contract regulate an individual's access to and use of tacit, non-proprietary knowledge and know how. ${ }^{20}$ The contractual obligations entered into by autonomous parties, and equitable default principles are 'relational' rather than proprietary, and they impose standards on personal conduct. In terms of innovation, their impact is critical: the most effective information exchanges are personal. They come about by person to person contact, and most importantly by the mobility of knowledgeable individuals between firms and organisations. People take their knowledge with them to work in different environments, new firms and organisations with distinct complementarities, and direct and daily interaction with new colleagues. These interactions and exchanges are productive of ideas, insights and innovation. The critical legal instruments that underlie them, that is, employment contracts, and associated principles of equity ${ }^{21}$ are further examined next.

\section{Incentives for individuals to innovate}




\section{A. Optimal conditions for individual creativity}

At the outset, this piece focussed on incentives for firms. I surmised that in today's socio-cultural and economic environment such incentives are so pervasive, that there is no demonstrable need for an additional statutory incentive to create or invent. That contention then pointed to a reconceptualising of patents as instruments to address competition failures in certain markets or industries, such as pharmaceuticals, which might effectively be addressed by tailored technology-monopolies.

But incentives to create must also be considered at the level of the individual rather than the firm. Not only do individuals in a mobile society act as critical diffusers of knowledge as argued in Part I, they are also the source of all invention. The creative genius 'myth' may rightly have been debunked in IP law, but there is no escaping the fact that new knowledge cannot be generated without the creative faculties, the mental processes of individuals. Nothing new in the practical arts comes about without the human mind. It is this insight that leads us to focus on the incentives that apply to individuals to create, to reveal, to communicate. However, in the modern environment individuals can rarely operate independently: they are dependent on firms and organisations which can accumulate and organise the complex and multifarious complementary resources that permit creative activity. The firm is the common environment for critical inter-personal exchanges. Most often, individuals are legally embedded in firms or other organisations by contractual employment relationships. Therefore the firm based employment context is the primary focus of attention here. 
Two interesting questions arise in this context: first, how to optimise incentives for individuals to invent, create, innovate in the firm environment; and second, how to optimise the conditions for the realisation of individuals' creative ideas and inventions. Innovation policy and management literature tends to focus on the first question: how to structure material incentives for employees most efficiently. In terms of patents this becomes a debate concerning ownership; rights to exploit a patented invention as between employer and employee; royalty rights; patenting premiums and the like, and also about the primacy of contract or the need for statutory intervention in this area.

But even though the incentive to innovate is universal, the micro-conditions for realisation of innovations are variable, which demands attention for the second issue: what are the optimal conditions for the realisation of the creative insights of an individual employee? Individual incentives should operate to encourage the revelation of creative ideas where the chances of realisation are the greatest. ${ }^{22}$ But what are the optimal conditions for revelation and realisation of new ideas? How do we generate or organise such conditions? These are exceedingly difficult and complex questions to attempt to answer in theory and a priori. Instead, I suggest a simpler starting point that creative individuals themselves are best able to identify and evaluate conditions that stimulate their own creativity. ${ }^{23}$ And therefore knowledgeable individuals should be free to exercise employment choices between firms and organisations that offer different conditions for creative activity.

Presuming that alternatives do exist, a number of conditions must be fulfilled for individuals to be able to make and realise such choices. First, they must have access 
to information concerning the resources of, and conditions within relevant firms; ${ }^{24}$ and second labour market conditions and the law must leave them at liberty to put their choices into effect by migrating between firms and organisations, whether on a concurrent or consecutive basis. If there is sufficient freedom to migrate between organisations individuals will be more likely to find the conditions that optimise opportunities for realisation.

\section{B. Relevant legal mechanisms}

In terms of the relevant legal mechanisms, because most creative individuals are employees we are substantially within the province of labour law. ${ }^{25}$ The latter takes us too far away from the present IPR context, but there is a close connection between labour law and aspects of intellectual property law relevant to mobility. These aspects are employee entitlement to statutory IPRs; and trade secrets and contracts law.

The predominant focus below is on the latter: legal restraints on individuals' ability to draw on previously acquired know-how will act as a disincentive to move, and also restrain an individual's creativity in a new environment. Mobility cannot have positive effects on creativity if individuals are not free to draw on knowledge they have previously gained. Some comments concerning employee entitlements to statutory IPR's are nonetheless appropriate here. If we favour the mobility of employees in full possession of their knowledge, experience, ideas and know-how their creative tools - then there are two broad preferences: one favouring employee IPR ownership, or at least participation; and another favouring dealing with inventions retrospectively and individually rather than prospectively and universally. 
In other words, the rights of ownership and exploitation should be dealt with at the time the employee makes the invention. ${ }^{26}$ This policy approach may appear counterintuitive to firm managers, who might incline towards the broadest possible $a$ priori claims over employee-IP, but experience shows that commercial outcomes are not necessarily less favourable for firms that are more prepared to negotiate with creative employees. ${ }^{27}$

However, if the crucial question is to what extent individuals are able to migrate with all their knowledge, conversely what rights an ex-employer can exercise over such knowledge, then property rights or ownership of inventions only provide part of the answer. With a view to mobility between firms (employers), equity and contract are as significant as patent ownership, if not more so. The freedom to use all knowledge held in the mind, all learning, insight, know-how and skills absorbed with a previous employer, without restraint, in new and different conditions which an individual considers more conducive to invention and creativity, is critical. Legally this freedom depends on how rules and principles deal with knowledge that is either not subject to property rights, or over which no property claims have been staked. Often this is compendiously and loosely referred to as tacit knowledge, or legally as know-how. The contract of employment may seek to resolve contested claims to such knowledge, but equity and the law concerning restraints of trade impose marked limitations on contractual terms in this regard.

In the absence of express contractual clauses, the equitable obligation of confidence imposes restrictions on the use of particular identifiable trade secrets post-termination. Other than in relation to those, the employee is generally absolutely free to use and 
deploy everything she has previously learned, whether or not she is now in direct competition with the ex-employer. However, the scope of the rights that employers enjoy over trade secrets under the mantle of the equitable obligation of confidence is both narrow and unpredictable. Narrow, because it extends no further than what can be properly particularised, demonstrated to be outside the public domain and communicated in circumstances of confidence. Unpredictable, because the dividing line between what is a trade secret and what is general know-how and experience lying outside the confines of trade secret protection is often very difficult to draw. ${ }^{28}$ What is more, there are various policy imperatives (freedom of competition, tools of trade theory and the like), and consequent principles underlying the law in this area, which do not generally favour the employer in a particular case.

An employer's ordinary reaction to this is to shore up its position by seeking to insert favourable terms into the contract of employment. These tend to take two forms, although there is considerable legal ingenuity in this area. The first is expansive confidentiality clauses; the second is covenants in restraint of trade. The latter are a well recognised weapon in the employer's armoury, but are subject to very severe restraints in scope and enforceability. The general policy of the law is to hold such covenants unenforceable. ${ }^{29}$ However, in exception to that rule, reasonable restraints will be enforced by the courts if they are demonstrably justified to protect particularised employer trade secrets. This means that the employer must be in a position to establish, if the covenant is challenged in court, that it has such trade secrets in its possession, exactly what they concern, and that the ex-employee had access to them (or generated them in the pursuit of her duties). Furthermore, it must establish that the prohibition on working in a certain area and industry for a certain 
time is reasonably adapted to protecting the employer's legitimate interests in its own trade secrets. The difficulty lies in predicting what a court will hold reasonable in the particular circumstances of a given case. ${ }^{30}$

In terms of express confidentiality clauses, the employer might be tempted to insert terms that include as much information as possible under the umbrella of contractual trade secrets protection. However, the courts have held that contracts cannot make trade secrets out of information that is in the public domain; and they equally demand particularisation. Abstract 'umbrella' terms that purport to cover otherwise unidentified items of information will often not be particular enough to enforce. But the alternative of identifying particular trade secrets in substance is of course difficult to do in an employment contract. It operates prospectively, intending to apply to as yet unidentified information that will emerge at some later date, either by way of the employee herself or in some other manner within the organisation. It may be possible to identify existing trade secrets at the time of entering into the employment contract, but usually it is too onerous to do so comprehensively. But it will be far more difficult, if not impossible to do in relation to future or anticipated trade secrets. So the employer may have little alternative but to refer to abstract categories ('the trade secrets', the 'confidential information' and so on) in the contract. However, when seeking to enforce such terms, he will be in no better position than when, in the absence of express provisions in the contract, relying on equity alone: having to establish what is a genuine trade secret, as opposed to general know-how the employee is entitled to use. And then the law has a further difficulty where an employee's ideas are inchoate: courts tend to limit the grant of equitable remedies 
where an idea is not fully worked out, its practical use not fully described and its commercial value uncertain.

Thus the law may superficially appear to favour the employer but in its particular application in fact tend to support an employee's right to leave and escape the exemployer's control over all her acquired knowledge, other than in relation to a narrow and difficult to prove category of genuine trade secrets. ${ }^{31}$ This favours employee mobility, and means that knowledgeable and creative individuals have a large and unrestrained measure of freedom to determine where to work - in other words, to decide where their chances of creative output, realisation and/or dissemination are optimal. If we accept, as suggested above, that individuals are the most capable of assessing optimal conditions for creative work and realisation, then this is positive. Rather than attempt to identify ideal conditions for creative work theoretically and $a$ priori, we can presume that those firms with the most conducive conditions will be most effective in attracting creative individuals, and will thus be most likely to survive and prosper.

However, two worrying trends invite some comment. The first is a tendency in some quarters to elevate notions of contractual autonomy, in particular in relation to knowledgeable (that is, well-educated) employees, above notions of public policy that require active policing of restraints of trade. ${ }^{32}$ The second is the fact that there is a dichotomy between the perception and the reality of legal rights in relation to restraints and broad confidentiality clauses. Although there may be severe doubts about enforceability of certain clauses and restraints, it may be that most employees are unwilling to challenge them in court, given the risks involved in doing so. 
Restraints that are unreasonable in terms of the law may in fact be observed in practice. Arguably this would be detrimental in terms of the policy settings discussed above.

\section{Conclusion}

I have highlighted the importance of thinking differently about incentives and innovation in two ways. First, at the level of the firm, I have argued that the focus should not be on incentives to innovate, because such incentives arguably pervade post-industrial societies. ${ }^{33}$ Rather the focus should be on patents as a legal device to enhance competition in markets that are not dynamic due to various factors, where there is reason to suppose that the problem can be effectively addressed by technological monopolies.

Additionally, I have argued that thinking about incentives must also focus on individuals. This requires thinking about which incentives will induce individuals to be inventive, but also about the ideal conditions for generating and realising creative output from individuals. Identifying those conditions theoretically or empirically is arguably too complex; a reasonable alternative is to accept individuals as rational maximisers of their own inventive or creative capacity. They are the best placed to make the ex post facto choice between existing firms and organisations as to which will maximise their chances of creative output. From that perspective it is beneficial to ensure, in terms of legal policy, that individuals have sufficient access to information to identify the firms with the most potential, and that they enjoy 
conditions of mobility with all their knowledge and know-how, so they can act on their preferences and transfer between organisations with a view to maximising their inventive output. This will encourage the realisation and diffusion, whether by commercialisation or otherwise, of their creative ideas.

\section{References:}

Abramowitz, M. (2007), ‘The uneasy case for patent races over auctions', Stanford Law Review, 60, 803-862.

Alford, W. (1995), To Steal a Book is an Elegant Offense, Pao Alto, California : Stanford University Press.

Arup, C. et al. (eds) (2006), Labour Law and Labour Market Regulation : essays on the construction, constitution and regulation of labour markets and work relationships, Sydney : Federation Press.

Ayres, I. and G. Parchomovsky (2007), ‘Tradable Patent Rights: A New Approach to Innovation', University of Pennsylvania, Institute for Law and Economics Research Paper No. 07-23, http://ssrn.com/abstract=1020276.

Bessen, J. (2008), Patent Failure, Princeton : Princeton University Press.

Duffy, J. (2007), ‘Inventing Invention: a case study of legal innovation’, Texas Law Review, 86, 1-72. 
Economides, N. and W. Hebert, (2008), 'Patents and Antitrust: Application to Adjacent Markets’, NET Institute Working Paper No. 07-07, http://ssrn.com/abstract=1013226 (forthcoming publication in the Journal on Telecommunications and High Technology Law).

Grushcow, J. (2004), 'Measuring Secrecy: A Cost of the Patent System Revealed', Journal of Legal Studies, 33, 59-84.

Jaffe, A and J. Lerner (2004) Innovation and Its Discontents: How Our Broken Patent System is Endangering Innovation and Progress, and What to Do About It, Princeton: Princeton University Press.

Janis, M. (2002), ‘Patent Abolitionism’, Berkeley Technology Law Journal, 17, 899952.

Kingston, W. (2004), 'Why patent harmonization is a Trojan horse’, European Intellectual Property Review, 59, 441-462.

Lichtman D. and M. Lemley (2007), ‘Rethinking patent law’s presumption of validity’, Stanford Law Review, 60, 45-72.

Macdonald, S. (2003), 'Bearing the Burden: Small Firms and the Patent System', Journal of Information, Law and Technology, 2003(1), http://www2.warwick.ac.uk/fac/soc/law/elj/jilt/2003_1/macdonald. 
Merges, R. (1999), ‘The Law and Economics of Employee Inventions', Harvard Journal of Law and Technology, 13, 1-54.

Moore, K. (2005), ‘Worthless Patents’, Berkeley Technology Law Journal, 20, 15211552.

Petrusson, U. (2004), Intellectual Property \& Entrepreneurship - Creating Wealth in an Intellectual Value Chain, Göteborg, Sweden: CTHB.

Schankerman, M. (1998), 'How valuable is patent protection', Rand Journal of Economics, 29, 77-107.

Schankerman, M. and A. Pakes (1986), 'Estimates of the Value of Patent Rights in the European Countries during the post-1950 Period', Economic Journal, 96, 1051-1076.

Scotchmer, S. (1999), 'On the Optimality of the Patent Renewal System’, Rand Journal of Economics, 30, 181-196.

Van Caenegem, W. (2002), ‘The Technicality Requirement, Patents Scope and Patentable Subject Matter in Australia', Australian Intellectual Property Journal, 13, 309-327.

Van Caenegem, W. (2003), 'Intellectual Property and the Idea of Progress', Intellectual Property Quarterly, 3, 237-256. 
Van Caenegem, W. (2007), 'Mobility of Creative Individuals, Trade Secrets and Restraints of Trade’, Murdoch eLaw Journal, 14(2), 265-279.

Van Ypersele, T. and S. Shavell (2001), 'Rewards versus Intellectual Property Rights', Journal of Law and Economics, 44, 525-547.

\section{Notes:}

1. Leigh Dayton, 'Cell Find Sidesteps Patent', Higher Education Section, The Australian, Wednesday 28 November 2007, p. 25.

2. The Australian Universities Quality Audit.

3. See Brendan O’Keefe, 'ANU told of ways to raise profile’, Higher Education Section, The Australian, Wednesday 28 November 2007, p. 26

4. See for example, Kingston (2004); Lichtman and Lemley (2007); Schankerman and Pakes (1986); Schankerman (1998); Moore (2005); Abramowitz (2007); Janis (2002); Bessen (2008); and Jaffe and Lerner (2004). In relation to weeding out valueless patents, see Ayres and Parchomovsky (2007). Patent renewals also indicate value attached to patents: see for example, Scotchmer (1999). As to alternatives to patents, see for example, Van Ypersele and Shavell (2001). 
5. Ranging from the personal and psychological to structural and economic factors, education and the like.

6. In today's complex technological environment this is generally speaking a rare occurrence.

7. In other words, the investment in research may be totally lost, in that there are no alternative or tangential uses of the results of R\&D.

8. As to how this came about, see Van Caenegem (2003); see also Alford (1995).

9. One illustration is the continuous renewal in the former of 'versions' of some basic product. The law tends to reflect this cultural given, for instance in relation to the requirement of inventiveness in patents law: see Duffy (2007).

10. Journals too numerous to list specialize in innovation policy and science policy. Some examples are Innovation: Management, Policy \& Practice; Creativity and Innovation Management; European Journal of Innovation Management; International Journal of Innovation Management; Prometheus; Research Policy; the Journal of Innovation Law and Technology; various US University Law and Technology journals, eg. the Berkeley Law and Technology Journal; the Harvard Law and Technology Journal.

11. See Petrusson (2004). 
12. If incentives to create are pervasive, the role of patents as incentives is diminished; but what about the other main benefit claimed for the patent system, that is, publication of information about inventions that would otherwise remain secret? If we accept that there is a sufficiently strong incentive to innovate without patents, then the logical consequence is that information about inventions will be published - not in the form of patent literature, but in reified form. Generally speaking inventions that can be exploited and kept secret at the same time are not patented. Further, there is considerable skepticism in the literature concerning the effectiveness of disclosure and diffusion by patent specifications (see for example, Macdonald (2003)). Others point to the fact that patenting requires a degree of secrecy in relation to information that may previously have been published freely in the academic disciplines, see for example, Grushcow (2004).

13. That is why the so-called first patent statute, the Statute of Monopolies, is actually no such thing, but a statute primarily abolishing the right of the Crown to grant monopolies. The antecedent period of monopolies was marked by a failure to introduce into England competitive technologies that were used elsewhere in Europe.

14. See text around notes 6 and 7. Furthermore, developing a taxonomy of these conditions is essential and it has not been sufficiently addressed to date.

15. For some interesting insights in relation to monopolies and patent rights, see Economides (2008). 
16. It is suspected that the most amenable markets are those where the technology component of the end-product is highest: contrast for instance the pharmaceuticals market, where the product is nearly $100 \%$ technology based, with supermarket retailing, where technology is a marginal component of the end product.

17. Or conversely, will not be either without beneficial effect, or actually detrimental to the innovation dynamic. This has relevance for recent debates concerning technology, for example, relating to non-technical inventions, computer programming and business methods; but also more broadly to creativity and innovation in design based industries such as fashion.

18. Often competitive research initiatives also multiply because of dispersed educational infrastructure, and disciplinary specialisation which impedes effective signalling and diffusion.

19. Some scholars emphasise that property rights such as patents perform exactly this function - enabling patentees to act as secure coordinators of the downstream, applied research process under the umbrella of a relatively broad patent monopoly. Others tend to favour narrower patent monopolies emphasising that proprietary patent rights can be a vehicle for the structured exchange, sharing and cross-licensing of knowledge assets between dispersed patent holders. These differing approaches are canvassed in Van Caenegem (2003). 
20. The scope of patents is limited: recorded knowledge, appropriable under the patent scheme, only concerns a small fraction of all the knowledge that needs to be shared or exchanged.

21. This is not to say that only employment relationships or interactions are significant in the innovation constellation. Where there is a complex network of dispersed but interdependent actors, knowledgeable intermediaries are also essential. Newer forms of interaction between private and public sectors, between education and commerce have added further to complex patterns of production, exchange and consumption of knowledge. This complexity requires intermediaries with the expertise and accumulated knowledge to deploy sophisticated legal, management, financial and accounting tools effectively. The importance of lawyers, of accountants, of commercial banks, of financial entrepreneurs and of other knowledge brokers and facilitators increases with the complexity of the environment. They all acquire a stake and some influence in the system, which will have its effect on its internal dynamics, growth and future development. All these interactions are underpinned by law, mostly contractual provisions concerning exchanges of knowledge and information, but also default rules of equity that govern professional interactions.

22. This is not a novel point: see for example, Merges (1999).

23. This approach borrows from a fundamental tenet of market economics: that individuals presented with ex post alternative consumption choices generated by multiple competing providers will more efficiently maximise their own welfare, than 
planners directing the supply of goods and services in reliance upon a priori assumptions about consumers’ preferences.

24. For example, what research is being done/ by whom/ in what context/ with what resources? Well informed employees require an effective publicity regime and quick and efficient diffusion of new knowledge, ideas and inventions. Obviously the patent literature is one way in which this is supposed to happen, but scepticism has been expressed at how effective the publication compulsion actually is, given the difficulties that exist in searching patent literature and databases (see above note 12). Nonetheless if we take both the mobility, and the access to information which makes it relevant for employees seriously, then this is a critical aspect of the patents system.

25. Although in the present fractured work environment contractors also play a significant role; see Arup et al. (2006).

26. This is not to suggest a mandatory model for every employment situation: naturally the proposed bias in favour of employees must be balanced with other policy considerations, including freedom of contract and party autonomy. There are also issues of efficiency and delay and the problem of employers being held to ransom. Most significantly, a 'retrospective’ approach invites a focus on process (an adequate and efficient framework for negotiation once an invention arises) rather than outcome (that the employer should own everything).

27. Although a close analysis of the cases tends to belie the general proposition that employers own intellectual property created by employees in employment: see for 
example, Victoria University of Technology v Wilson [2004] VSC 33 (18 February 2004); University of Western Australia v Gray (No 20) [2008] FCA 498 (17 April 2008); and also Polwood Pty Ltd v Foxworth Pty Ltd [2008] FCAFC 9 (18 February 2008) concerning ownership of inventions.

28. See Faccenda Chicken Limited v. Fowler [1987] Ch. 117 and more recent cases, as canvassed in Van Caenegem (2007).

29. An established principle that goes back to the decision in Maxim-Nordenfeldt Gun Co. v. Nordenfeldt [I893] I Ch. 630, [I894] A. C. 535.

30. Employers try to deal with this difficulty in different ways, for instance by including step-wise or cascade clauses. They also deploy alternatives such as 'garden leave’.

31. This probably encourages employers to seek the inclusion of terms in many contracts of employment that are never in fact tested but if they were, would be found invalid and unenforceable. There is thus a possible dichotomy between the actual conduct based on perceived law, and what the law actually is. This is a grey area about which empirical research could perhaps tell us more.

32. See Callinan J's reasons in Maggbury Pty Ltd v Hafele Aust Pty Ltd [2001] HCA 70; 210 CLR 181; 185 ALR 152; 76 ALJR 246 (13 December 2001). 
33. One additional way in which this is demonstrated is the abundance of stories about the personal benefits derived from innovation - the hero stories of wealthy inventors. Statistically however these stories may be irrelevant compared to the number of unheard of failures. 